\title{
ВИЗНАЧЕННЯ ТИПУ ПОВЕДІНКИ КУРЦЯ У ВІДВІДУВАЧІВ ПОЛІКЛІНІКИ ЗАЛІЩИЦЬКОЇ ЦЕНТРАЛЬНОЇ РАЙОННОЇ КОМУНАЛЬНОЇ ЛІКАРНІ
}

\author{
X. С. Чабан, I. Я. Криницька \\ Заліщицька иентральна районна комунальна лікарня \\ ДВНЗ «Тернопільський державний медичний університет \\ імені І. Я. Горбачевського МОЗ Украӥни»
}

Визначено тип поведінки курця у відвідувачів, які проходили профілактичні огляди в поліклініці Заліщицької центральної районної комунальної лікарні. Звернено увагу на гендерні відмінності поведінки курця у досліджуваній групі респондентів.

\section{THE DETECTION OF SMOKER BEHAVIOR TYPE AMONG THE VISITORS OF ZALISHCHYKY CENTRAL DISTRICT MUNICIPAL HOSPITAL}

\author{
H. S. Chaban, I. Ya. Krynytska \\ Zalishchyky Central District Municipal Hospital \\ I. Horbachevsky Ternopil State Medical University
}

The smoker behavior type among the visitors who had preventive examinations in the clinic of Zalishchyky Central District Municipal Hospital has been studied. Attention is drawn to the gender differences in smoker behavior type of the respondents of investigated group.

Вступ. У сучасних умовах куріння тютюну перетворилося у величезне соціальне зло і однією з його причин $є$ тютюнова індустрія. Виробництво тютюну в світі становить близько 5,7 млн тонн на рік, а середньосвітове споживання складає 1650 цигарок на людину в рік [7].

Згідно з глобальною доповіддю Всесвітньої організації охорони здоров'я та Національного інституту онкології Сполучених Штатів Америки «Економічні аспекти тютюну та контролю над тютюном», щороку світова економіка втрачає понад трильйон доларів через збільшення затрат на медичну допомогу курцям та втрату працездатності. Більше того, хвороби, спричинені курінням, забирають життя 6 млн осіб щороку у світі [10].

За даними ВОО3, в Україні нараховують майже 9 млн курців. Розповсюдженість куріння серед чоловіків в Україні - більше 50 \%, серед жінок - 20 \% і більше [6, 9]. Україна щорічно втрачає більше 3 млрд доларів через куріння населення. Це зумовлено тим, що курці стають непрацездатними внаслідок хвороб,

(c) Х. С. Чабан, І. Я. Криницька, 2017 спричинених курінням, і не можуть фінансово забезпечити себе та свої сім'ї [4].

Куріння є провідним фактором ризику таких хронічних неінфекційних захворювань, як ішемічна хвороба серця, артеріальна гіпертензія, атеросклеротична хвороба судин головного мозку, атеросклероз периферичних судин, хронічна обструктивна хвороба легень, гастрити, гастродуоденіти, злоякісні новоутворення та інші $[1,2,5,8]$. Так, ризик передчасної смерті від ішемічної хвороби серця серед чоловіків, які курять у віці 40-59 років і жінок у віці 30-69 років в 3 рази перевищує аналогічний показник серед осіб, які не курять [3].

У літературних джерелах багато робіт присвячено дослідженню впливу куріння на організм. Однак ряд аспектів комплексної оцінки статусу курця осіб, які курять, залишений без належної уваги. Тому метою дослідження було визначення гендерних особливостей типу поведінки курця у відвідувачів, які проходили профілактичні огляди в поліклініці Заліщицької центральної районної комунальної лікарні.

Основна частина. У роботі проведено дослідження 104 відвідувачів, які проходили профілактичні 
огляди в поліклініці Заліщицької центральної районної комунальної лікарні, схильних до регулярного активного куріння.

Критеріями включення пацієнтів у групу спостереження були: регулярне активне куріння (від 1 сигарети щодня і частіше); вік від 18 до 60 років.

Критерії виключення пацієнтів з групи: вік менше 18 і більше 60 років; нерегулярне куріння (менше 1 сигарети на добу), куріння в минулому; тяжка серцева недостатність; хронічні захворювання внутрішніх органів у стадії загострення; системні захворювання сполучної тканини; злоякісні захворювання, відмова від участі в дослідженні.

Контрольна група була представлена 30 практично здоровими особами (12 жінок і 18 чоловіків) віком від 18 до 60 років. Середній вік серед обстежених чоловічої статі становив $(35,4 \pm 11,5)$ року. Середній вік серед обстежених жіночої статі склав $(31,2 \pm 8,4)$ року.

Куріння тютюну належить до поведінкових характеристик людини. У кожного курця є свої, тільки йому притаманні особливості поведінки. Поведінка курця - це комплексна характеристика індивідуальних особливостей поведінки людини, яка курить (причини куріння, характер куріння іт. д.). Для визначення типу поведінки курця використали анкету, розроблену Д. Хорном, яка заповнювалася пацієнтами власноруч (табл. 1).

На основі анкети виділяють шість типів поведінки курця: «стимуляція», «гра з сигаретою», «розслаблення», «підтримка», «жага», «рефлекс».

Тип поведінки курця в більшості випадків має змішаний характер, але опитування за анкетою Д. Хорна дозволяє виділити домінуючий тип поведінки курця, визначити ситуації, пов'язані з курінням. Анкета складається з 18 питань: 6 блоків по 3 запитання. Відповідь на кожне питання оцінюється за 5-бальною шкалою (1 - ніколи; 2 - рідко; 3 - не дуже часто; 4 - часто, 5 - завжди). В опитувальнику наведені твердження, що описують відчуття і думки самого курця. Пропонують відповісти: «Наскільки ці відчуття характерні для Вас? Як часто Ви це відчуваєте?». Блоки запитань характеризують 6 типів поведінки курця (табл. 2).

таблиця 1. Анкета Д. Хорна для визначення типу поведінки курця

\begin{tabular}{|c|c|c|c|c|c|c|}
\hline № 3/ח & Запитання & Завжди & Часто & Не дуже часто & Рідко & Ніколи \\
\hline 1 & $\begin{array}{l}\text { Я курю для того, щоб зняти втому, залишатися } \\
\text { бадьорим (-ою) }\end{array}$ & 5 & 4 & 3 & 2 & 1 \\
\hline 2 & $\begin{array}{l}\text { Часткове задоволення від куріння я отримую ще } \\
\text { до закурювання, розминаючи цигарку }\end{array}$ & 5 & 4 & 3 & 2 & 1 \\
\hline 3 & $\begin{array}{l}\text { Куріння приносить мені задоволення і дозволяє } \\
\text { розслабитися }\end{array}$ & 5 & 4 & 3 & 2 & 1 \\
\hline 4 & Я закурюю цигарку, коли дратуюся, серджуся & 5 & 4 & 3 & 2 & 1 \\
\hline 5 & $\begin{array}{l}\text { Коли у мене закінчуються сигарети, мені } \\
\text { видається нестерпним час, поки я їх не дістану }\end{array}$ & 5 & 4 & 3 & 2 & 1 \\
\hline 6 & Я закурюю автоматично, не помічаючи цього & 5 & 4 & 3 & 2 & 1 \\
\hline 7 & Я курю, щоб стимулювати себе, підняти тонус & 5 & 4 & 3 & 2 & 1 \\
\hline 8 & $\begin{array}{l}\text { Часткове задоволення мені приносить сам } \\
\text { процес закурювання }\end{array}$ & 5 & 4 & 3 & 2 & 1 \\
\hline 9 & Куріння приносить мені задоволення & 5 & 4 & 3 & 2 & 1 \\
\hline 10 & $\begin{array}{l}\text { Я закурюю сигарету, коли засмучений (-а) або } \\
\text { відчуваю себе некомфортно }\end{array}$ & 5 & 4 & 3 & 2 & 1 \\
\hline 11 & Я дуже добре відчуваю ті моменти, коли не курю & 5 & 4 & 3 & 2 & 1 \\
\hline 12 & $\begin{array}{l}\text { Я закурюю нову цигарку, не помічаючи, що } \\
\text { попередня ще не догоріла в попільничці }\end{array}$ & 5 & 4 & 3 & 2 & 1 \\
\hline 13 & $\begin{array}{l}\text { Я закурюю, щоб підбадьорити себе, відчути } \\
\text { наснагу, піднесення }\end{array}$ & 5 & 4 & 3 & 2 & 1 \\
\hline 14 & $\begin{array}{l}\text { Коли я курю, задоволення я отримую, } \\
\text { випускаючи дим і спостерігаючи за ним }\end{array}$ & 5 & 4 & 3 & 2 & 1 \\
\hline 15 & $\begin{array}{l}\text { Я хочу закурити, коли зручно влаштувався } \\
\text { (-лась) і розслабився (-лась) }\end{array}$ & 5 & 4 & 3 & 2 & 1 \\
\hline 16 & $\begin{array}{l}\text { Я закурюю, коли відчуваю себе пригніченим } \\
\text { (-ною) і хочу забути про всі неприємності }\end{array}$ & 5 & 4 & 3 & 2 & 1 \\
\hline 17 & $\begin{array}{l}\text { Якщо я деякий час не курю, я відчуваю «голод» } \\
\text { за цигаркою }\end{array}$ & 5 & 4 & 3 & 2 & 1 \\
\hline 18 & $\begin{array}{l}\text { Виявивши у себе в роті сигарету, я не можу } \\
\text { пригадати, коли закурив (-ла) її }\end{array}$ & 5 & 4 & 3 & 2 & 1 \\
\hline
\end{tabular}


Таблиця 2. Визначення типу поведінки курця за анкетою Д. Хорна

\begin{tabular}{|c|l|}
\hline Кодування питань за блоками & \\
\hline $1+7+13$ & Стимуляція \\
\hline $4+10+16$ & Підтримка \\
\hline $2+8+14$ & «Гра з сигаретою» \\
\hline $5+11+17$ & Жага \\
\hline $3+9+15$ & Розслаблення \\
\hline $6+12+18$ & Рефлекс \\
\hline
\end{tabular}

Інтерпретація відповідей проводиться за сумою трьох запитань відповідного блоку: сума балів 11 і більше вказує, що анкетований курить саме з цієї причини; сума балів від 7 до $11 \in$ межовою і говорить про те, що це деякою мірою може бути причиною куріння; сума менше 7 - даний тип куріння для респондента не характерний.

Характеристика типів поведінки курця: 1 тип - «Стимуляція». Людина, яка курить, вірить, що сигарета має стимулювальну дію: підбадьорює, знімає втому. Курять, коли робота не ладиться. У курців із даним типом відзначається високий ступінь психологічної залежності від нікотину. У них часто спостерігають астенію і вегетосудинну дистонію; 2 тип - «Гра з сигаретою». Людина неначе «грає» в куріння. Їй важливі «курильні» аксесуари: запальнички, попільнички, сигарети. Нерідко вона прагне випускати дим на свій манер. В основному курять у ситуаціях спілкування, «за компанію». Курять мало, зазвичай 2-3 сигарети на день; 3 тип - «Розслаблення». Курять лише у комфортних умовах. За допомогою куріння людина отримує «додаткове задоволення» до відпочинку. Кидають курити довго, багато разів повертаючись до куріння; 4 тип - «Підтримка». Цей тип куріння насамперед стосується ситуацій хвилювання, емоційного напруження, дискомфорту. Курять, щоб стримати гнів, подолати сором'язливість, налаштуватися, розібратися в неприємній ситуації. Ставляться до куріння як до засобу, що знижує емоційне напруження; 5 тип - «Жага». Даний тип куріння зумовлений фізичною залежністю від тютюну. Людина закурює, коли знижується концентрація нікотину в крові. Курить в будь-якій ситуації, всупереч заборонам; 6 тип - «Рефлекс». Курці даного типу не тільки не усвідомлюють причин свого куріння, але часто не помічають сам факт куріння. Курячи автоматично, людина може не знати, скільки сигарет викурює на день, курить багато: 35 і більше сигарет на добу. Курять частіше за роботою, ніж у години відпочинку; чим інтенсивніша робота, тим частіше в руці сигарета.

При оцінці типів поведінки курця у чоловіків було виявлено, що провідним типом у більшості респондентів $\epsilon$ тип «підтримка», який був виявлений у $52,5 \%$ (рис. 1).

На другому місці за частотою виявлення - тип «Стимуляція» $(30,5$ \%), на третьому місці - тип «Жага» $(11,0 \%)$.

У групі жіночої статі провідним типом у більшості респондентів $\epsilon$ також тип «Підтримка», який був виявлений у 58,4 \% (рис. 2). На другому місці за частотою виявлення - тип «Розслаблення» (14,5\%), на третьому місці - тип «Гра з сигаретою» (11,0 \%).

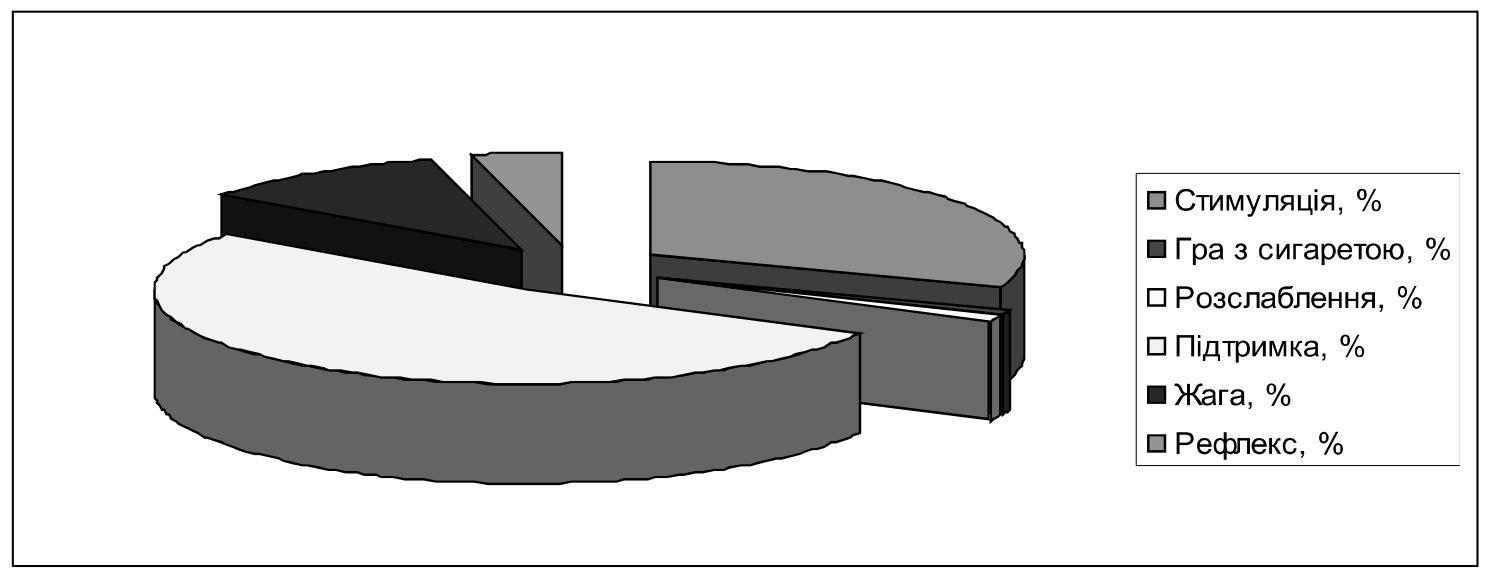

Puc. 1. Розподіл респондентів чоловічої статі за типом поведінки курця. 


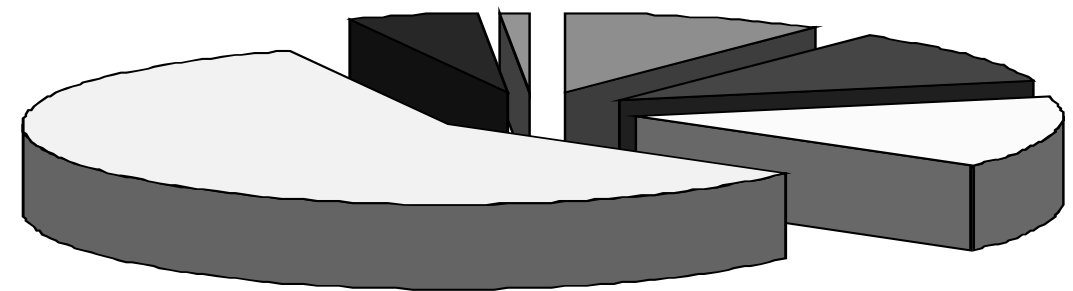

Puc. 2. Розподіл респондентів жіночої статі за типом поведінки курця.

Висновки. Тип поведінки курця відвідувачів поліклініки Заліщицької центральної районної комунальної лікарні має виражені гендерні особливості. Отримані дані про поведінку курця відвідувачів поліклініки

\section{СПИСОК ЛІТЕРАТУРИ}

1. Архіпова Г. І. Вплив тютюнопаління на організм людини / Г. І. Архіпова, Ю. С. Макаренко // Вісник НАУ. 2012. - № 3. - С. 140-142.

2. Бабанов С. А. Роль табакокурения в развитии хронических неспецифических заболеваний легких (обзор литературы) / С. А. Бабанов // Здравоохранение Российской Федерации. - 2002. - № 1. - С. 53-55.

3. Драпкина О. М. Курение и ассоциированные с ним проблемы в практике кардиолога / О. М. Драпкина // Артериальная гипертензия. - 2010. - Т. 16, № 2. - С. 164-169.

4. Контроль над тютюном в Україні. Другий Національний звіт. - К. : МОЗ України, ДУ «Український інститут стратегічних досліджень МОЗ України», 2014. - 128 с.

5. Курение и сердечно-сосудистая система / Н. А. Барбараш, Л. С. Барбараш, О. Л. Барбараш [и др.] // CardioСоматика. - 2013. - № 1. - С. 44-47.

6. Оцінка динаміки поширеності тютюнокуріння в Україні / К. С. Красовський, Т. І. Андреєва, А. А. Григоренко, Н. А. Бутильська // Вісник соціальної гігієни та організації охорони здоров'я України. - 2009. - № 2. - С. 91-99. рекомендується використовувати при плануванні та проведенні профілактичних заходів популяційного та індивідуального характеру.

7. Пікас О. Б. Про стан куріння цигарок у сучасних умовах, його вплив на виникнення захворювань в організмі людини (огляд літератури) / О. Б. Пікас // Буковинський медичний вісник. - 2015. - Т. 19, № 4 (76). - С. 227-230.

8. Хронічне обструктивне захворювання легень: етіологія, патогенез, класифікація, діагностика, терапія (проект національної угоди) / Ю. І. Фещенко, Л.О.Яшина, О. Я. Дзюблик [та ін.] // Український пульмонологічний журнал. - 2013. - № 3. - С. 7-12.

9. Эндотелий кровеносных сосудов новорожденных потомков курящих родителей / Г. И. Губина-Вакулик, Т. В. Горбач, В. Ю. Юнусов [та ін.] // Современная педиатрия. - 2016. - № 6 (78). - С. 56-59.

10. U.S. National Cancer Institute and World Health Organization. The Economics of Tobacco and Tobacco Control. National Cancer Institute Tobacco Control Monograph 21. NIH Publication No. 16CA8029A.Bethesda, MD: U.S. Department of Health and Human Services, National Institutes of Health, National Cancer Institute; and Geneva, CH: World Health Organization; 2016. Режим доступу: https://cancercontrol.cancer.gov/brp/tcrb/monographs/21/ docs/m21_complete.pdf 